\title{
CORRUPTION, SHADOW ECONOMY AND ECONOMIC GROWTH: AN EMPIRICAL SURVEY ACROSS THE EUROPEAN UNION COUNTRIES
}

\author{
Sorin Nicolae Borlea PhD \\ "Vasile Goldis" Western University of Arad, Romania \\ email: snborlea@yahoo.com \\ Monica Violeta Achim PhD. habil. \\ "Babes-Bolyai" University, Cluj-Napoca, Romania \\ email: monica.achim@econ.ubbcluj.ro \\ Monica Gabriela A. Miron PhD.Candidate \\ "Babes-Bolyai" University, Cluj-Napoca, Romania \\ email: gtepuse@yahoo.com
}

(Received March 2017; Accepted May 2017)

\begin{abstract}
This study was carried out to empirically investigate the relationships between corruption and shadow economy among the European Union countries, over the period 2005-2014. Moreover, since one would expect corruption and shadow economy to be more common in poorer countries, this study was therefore carried out to determine how corruption and shadow economy affect economic development. The empirical findings of this study confirm a high and positive relationship between corruption and shadow economy, therefore a higher level of corruption involves a higher level of shadow economy. Regarding the influence of corruption and shadow economy on economic growth, a high and negative relationship was found. This means that increasing corruption and shadow economy negatively affects economic growth.
\end{abstract}

Key words: Corruption, shadow economy, economic growth.

Jell classification: E26, K42, H26

\section{Introduction}

Corruption and shadow economy or underground are two destructive activities, which also go together, undermining democratic governance and the rule of law, and negatively affects economic development. According to Transparency International (2015), corruption is defined as "an abuse of entrusted power for private gain." Most literature on corruption are focused on bribery or private gain . This private gain is taken by entrepreneurs, in order to avoid taxation and regulation or to win public contracts. Various studies have shown that corruption negatively affects business and economic developments (Mauro, 1995; Djankov et al., 2002; Dreher and Schneider, 2006; Sahakyan and Stiegert, 2014). 
In comparison with corruption, shadow economy (also known as "underground" or "informal" economy) appears to be a more complex phenomenon. According to Shelak (1997), shadow economy includes activities which produce goods branded illegally, drug trafficking, commercial compulsion and prostitution, loan sharking, illegal gambling, trade-off, hiring of illegal immigrants, activities carried on by their own, hidden income and tax fraud. In order to obtain the best measure of shadow activities, Torgler and Schneider (2007) and Schneider et al. (2005, 2010, 2011, 2013, 2015) pointed out that shadow economy includes all "market-based legal production of goods and services that are deliberately concealed from public authorities for the following reasons: (1) to avoid payment of income, value added or other taxes; (2) to avoid payment of social security contributions; (3) to avoid having to meet certain legal labor market standards, such as minimum wages, maximum working hours, safety standards, etc.; and (4) to avoid complying with certain administrative procedures, such as the completion of statistical questionnaires or other administrative forms." Under this view, shadow economy has two main components: The first component, which represents a large share of shadow economy, is undeclared work. It refers to the wages that workers and businesses do not declare to avoid taxes or labor market regulation. The second component is represented by business underreporting income to avoid some of the tax burden.

Several studies have associated shadow economy (or informal sector) with low productivity and low economic development. For instance, shadow economy has a lower share in high income countries, while counting for as much as $70 \%$ of lowincome African economies (Kirchler, 2007).

Both corruption and shadow economy seem to have in common circumvention of regulations, payment of taxes and thus lower tax revenues, increase public expenditures and hamper productivity and growth. The relationship between corruption and shadow economy has little been analyzed and the results are not very clear (Dreher and Schneider, 2006; Buehn and Schneider, 2009). Therefore, this empirical study was carried out to investigate the relationships between corruption and shadow economy. Moreover, since one would expect corruption and shadow economy to be more common in poorer countries, this study was conducted to also investigate how corruption and shadow economy affect economic development.

This study is structured as follows: In the next section (2), the theoretical considerations are presented, according to how the main working hypothesis is stated. In section 3, the methodology and data sources are designed, and the variables are also described. Section 4 reveals the results of the hypotheses test along with proper discussion. Lastly, conclusions are drawn, which include a 
summary and a brief discussion on the policy implications, the limitations and the avenues for future research.

\section{Literature review}

In the investigation of research literature, it seems that the relationship between corruption and shadow economy is still not very clear, in terms of being either positive or negative (Johnson et al., 1997; Dreher and Schneider, 2006; Buehn and Schneider, 2009). Some authors (Weber, 2005; Mocan, 2008) have explained this using different measures or different controlling factors. Another category of authors (Choi and Thum, 2005; Dreher and Schneider, 2006; Virta, 2007) found that this relationship depends on the regional economic development of the country. Dreher and Schneider (2006) found that in low income countries, the public goods provided by the official sector are less efficient than in high income countries and this is the reason why numerous entrepreneurs (such as owners of restaurants, bars, saloonists or even bigger production companies) pay bribe to stay unofficial. Thus, the relationship between corruption and shadow economy has been found to be positive. On the other hand, in high income countries, public goods are more efficient and only small firms take the option of going underground to pay bribes. On the other hand, the big companies often bribe officials to get a contract from the public sector (e.g. the construction sector). So, this contract is then conducted in the official sector not in the unofficial one. For these reasons, in high income countries, the relationship between corruption and shadow economy has been found negative.

Based on the fact that different types of bribe may have different consequences with respect to shadow economy, Virta (2007) investigated the relationship between corruption and shadow economy based on regions. He theorized that such corrupt practices differ among regions of the world, being very common in some regions. He further pointed out that bribes to obtain projects have different consequences with respect to shadow economy size than bribes paid to lower taxes. A negative relationship between corruption and shadow economy was found among countries in the tropic region, because in this region, bribe to officials is commonly paid to stay official.

However, several research literature (Fjeldstad 1996, 2003; Buehn \& Schneider, 2009; Kaufman, 2010; Ivanyna et al., 2010; Ghosh and Neanidis, 2011) have shown the destructive role of corruption and bribing of officials to avoid taxes and staying in shadow. Fjeldstad $(1996,2003)$ also used the term "fiscal corruption" in relation to the fiscal role of corruption. Under this view, as corruption increases, the shadow activities are also expanded, thus a positive relationship is expected between them. Johnson et al. (1997) created a complex model of corruption in 
relation with the official and unofficial economy. It was found that corruption functions like a tax on firms in the official economy and drives them underground. Following this view, Buehn and Schneider (2009) also found a positive relationship between corruption and shadow economy.

This study determined the consequences of bribing officials with respect to shadow economy size and more specifically, if increasing corruption would result in the firm remaining largely unofficial. Therefore, the following hypotheses are proposed:

Hypothesis 1. The higher level of corruption is associated with a higher level of shadow economy.

An important strand in literature enhances the destructive role of corruption on economic growth and a high level of corruption has been found to be associated with low income countries.

The World Bank (2009) identified corruption as one of the greatest obstacles to economic growth, social development, and reduction of poverty. Husted (1999) argued that "since the level of development is related to the overall level of resource munificence, one would expect corruption to be more common in the less developed economies". De Rosa et al. (2010) obtained a 0.81 correlation between GDP per capita and the level of corruption. In the same view, Treisman (2000) and Paldam $(2001,2002,2009)$ argued that corruption is a poverty driven disease, which vanishes as the country becomes richer.

A lot of evidences have suggested that corruption has a negative effect on economic development, being an impediment to increasing investment (Mauro, 1995; Paldam, 2009), absorption of European funds (Achim and Borlea, 2015), efficiency in fiscal policy (Fjeldstad, 1996, 2003; Kaufman, 2010; Ivanyna et al., 2010) and finally on economic growth. For instance, Kaufman (2010) found a strong relationship between corruption and fiscal deficits in industrialized countries. Further, he also found that corruption lowers tax revenues, increases public expenditures, affects productivity, competitiveness and growth. In the same view, Ivanyna et al. (2010) pointed out that increasing corruption results to a decrease in government revenues and hampers economic growth.

Further, by investigating the findings of Schneider and Klingmair (2004), the highest rates of shadow activities were found to be associated with developing and in transition countries. According to Kirchler (2007), in Africa and South America, $41 \%$ of economic activities are clandestine. Orviska and Hudson (2002) found that in developed countries, tax fraud is estimated at $20 \%$ of the total income, and in developing countries the percentage is even higher. 
However, another strand in literature, which empirically documents contrary findings, can be discussed. Jiang and Nie (2014) conducted an empirical study on the China miracle of continuing high GDP growth by the prevalence of government corruption. They explained this, by the fact that in countries with a low quality of governance (like China), corruption may actually foster resource allocation and increase productivity. Similar results were reported by Beck and Maher (1986) who found that, in the absence of penalties for bribery, supplier firms would be indifferent between bribery and bidding institutions. Thus, corruption may be used as a way to obtain higher price of business opportunities.

Zaman and Goschin (2015) highlighted that shadow economy, especially in corrupt countries, represents an important buffer for solving many problems such as high rate of unemployment, future usage of black money in the official economy, and local efficient use of public goods, based on market principles in situation in which goods are used by a limited number of beneficiaries (private/public local beneficiaries) who pay different and voluntary-based contributions. “

In summary, this study is in support of the expectation that corruption and shadow economy would be more common in poorer countries. Thus, this study was conducted to investigate whether a high level of corruption and shadow economy may hamper economic growth. The following hypotheses are also stated:

Hypothesis. 2 The higher level of corruption lowers economic growth. Hypothesis. 3 The higher level of shadow economy lowers economic growth.

\section{Methodology and data}

This study was conducted on European Union (EU) member countries, which consisted of 28 states at the time of this study including: Austria (AUT), Belgium (BEL), Bulgaria (BGR), Croatia (HRV), Cyprus (CYP), Czech Republic (CZE), Denmark (DNK), Estonia (EST), Finland (FIN), France (FRA), Germany (DEU), Greece (GRC), Hungary (HUN), Italy (IT), Ireland (IRL), Latvia (LVA), Lithuania (LTU), Luxembourg (LUX), Malta (MLT), Netherlands (NLD), Poland (POL), Portugal (PRT), Romania (ROU), Slovakia (SVK), Slovenia (SVN), Spain (SWE), Sweden (SWE), and United Kingdom (GBR).

Table 1 shows the variables used and data sources of the hypotheses test.

This study dealt with the period 2005-2014, for which all required data are available for all European Union countries (28 countries). In order to meet the objective of this study, the Ordinary Least Square (OLS) regression analysis was conducted along with correlation coefficients and ANOVA using a cross-section data and average values for the years 2005-2014. All necessary validation procedures were performed to ensure that the results are statistically significant. 
Borlea SN., Achim MV., Miron MG. (2017)

Corruption, shadow economy and economic growth: An empirical survey across the European Union countries

Table 1. Variables and data sources.

\begin{tabular}{|c|c|c|c|c|}
\hline Variable Name & $\begin{array}{c}\text { Type of } \\
\text { variable }\end{array}$ & Description & Source & $\begin{array}{c}\text { No. of sampled } \\
\text { countries }\end{array}$ \\
\hline $\begin{array}{l}\text { Corruption } \\
\text { Perceptions Index } \\
\text {-CPI index- } \\
\text { (COR) }\end{array}$ & $\begin{array}{l}\text { Independent } \\
\text { variable }(\mathrm{H} 1)\end{array}$ & $\begin{array}{l}\text { It range from } 0 \\
\text { (highly corrupt) to } \\
100 \text { (very clean). A } \\
\text { higher level of } \\
\text { corruption means a } \\
\text { higher level of CPI } \\
\text { index. }\end{array}$ & $\begin{array}{l}\text { Transparency } \\
\text { International, } \\
2005-2014 .\end{array}$ & 175 countries \\
\hline $\begin{array}{l}\text { Shadow economy } \\
\text { (SE) }\end{array}$ & $\begin{array}{l}\text { Independent } \\
\text { variable }(\mathrm{H} 1) \\
\text { Dependent } \\
\text { variable }(\mathrm{H} 3) \\
\end{array}$ & $\begin{array}{l}\text { Expressed as a } \\
\text { percent of shadow } \\
\text { economy in GDP }\end{array}$ & $\begin{array}{l}\text { The databases of } \\
\text { Schneider } \\
(2015), 2003- \\
2014\end{array}$ & $\begin{array}{l}31 \text { countries ( } 28 \\
\text { EU countries and } \\
3 \text { non EU } \\
\text { countries) } \\
\end{array}$ \\
\hline $\begin{array}{l}\text { GDP Per capita } \\
\text { (GROWTH) }\end{array}$ & $\begin{array}{l}\text { Dependent } \\
\text { variable }(\mathrm{H} 2 \text {, } \\
\mathrm{H} 3)\end{array}$ & $\begin{array}{l}\text { GDP per capita } \\
\text { (current US\$. GDP } \\
\text { per capita is gross } \\
\text { domestic product } \\
\text { divided by midyear } \\
\text { population }\end{array}$ & $\begin{array}{l}\text { World Bank, } \\
\text { 1990-2014 }\end{array}$ & $\begin{array}{l}247 \text { countries } \\
\text { and region }\end{array}$ \\
\hline
\end{tabular}

\section{Results and discussion}

\subsection{Descriptive statistics}

In order to better understand the empirical findings, descriptive statistics were used.

The top European Union countries are shown in Graph 1 based on the level of corruption (reflected by CPI index). As shown in the graph, among the EU Countries, for the analyzed period of 2005-2014, Romania registered the highest level of corruption followed by Bulgaria, Greece, Hungary and Italy. In contrast, the Nordic countries such as Denmark, Finland, Sweden, Netherlands and Luxembourg, recorded the lowest level of corruption.

As shown in Graph 2 and Table 2, the level of shadow economy for all EU countries is about $19.93 \%$ (as percent in GDP), which means that in average, about one-fifth of the EU GDP is lost due to shadow economy over the period 20052014. The highest levels of shadow economy are found in Bulgaria, Romania, and Hungary with about 28 to $32 \%$. On the contrary, Austria, Luxembourg, Netherlands and the United Kingdom recorded the lowest level of shadow economy, which ranges between 8 to $10 \%$.

As shown in Graph 3, the lowest levels of living standards (measured by GDP per capita) are generally found among countries belonging to the former communist bloc. These countries include Bulgaria which has the lowest GDP per capita, 
followed by Romania, Poland, Latvia, Hungary, Croatia and Estonia. At the opposite pole is Luxembourg, followed by the Nordic countries (Denmark, Sweden, Ireland, Netherlands and Finland). A comparative analysis of the data of Graphs 1 and 3 easily revealed that countries with the lowest living standards are faced with the highest level of corruption; these two phenomena are associated with each other. Among the EU countries, Romania and Bulgaria have the lowest living standard, followed by other post-communist countries such as Croatia, Hungary, Poland, Lithuania, Czech Republic, and Slovakia. On the contrary, Luxembourg has the highest standard of living (over 100 thousand USD as GDP per capita), followed by the Nordic countries (Denmark, Sweden, Ireland, Netherlands and Finland), which range from 47 to 57 thousand USD as GDP per capita.

Based on the analyses of data contained in Graphs 1 to 3, it can be said that the highest levels of corruption and shadow economy are in countries with the lowest standard of living. Thus, this study's hypotheses were well stated.

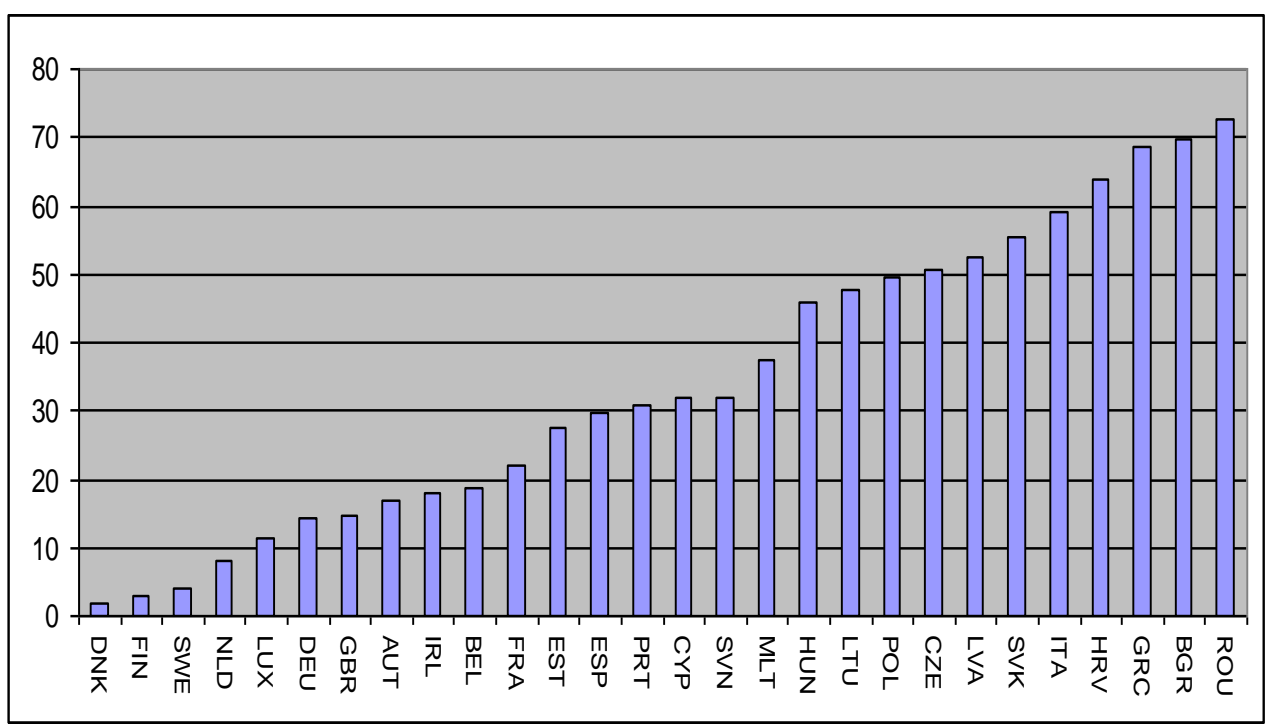

Graph 1. Corruption (as CPI index) in EU countries between the period 2005-2014 (in average). 
Borlea SN., Achim MV., Miron MG. (2017)

Corruption, shadow economy and economic growth: An empirical survey across the European Union countries

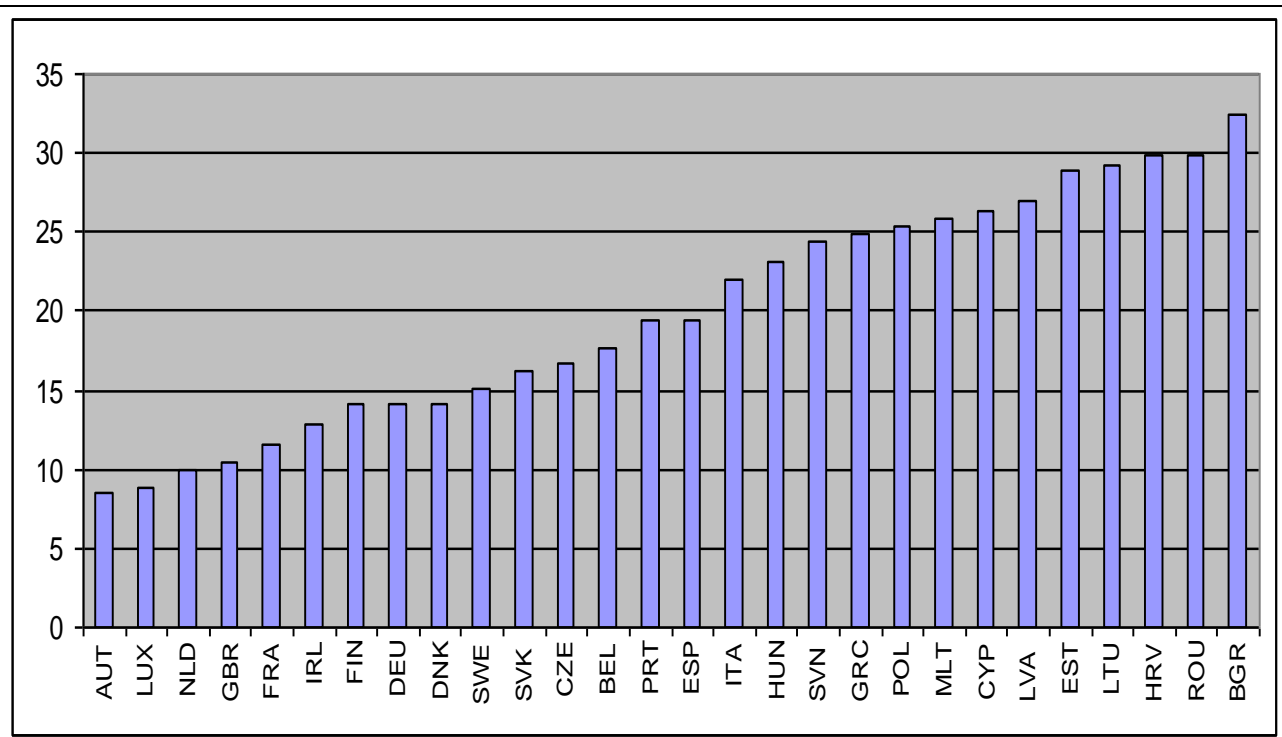

Graph 2. Shadow economy ( $\%$ in GDP) in EU countries between the period 2005-2014 (in average)

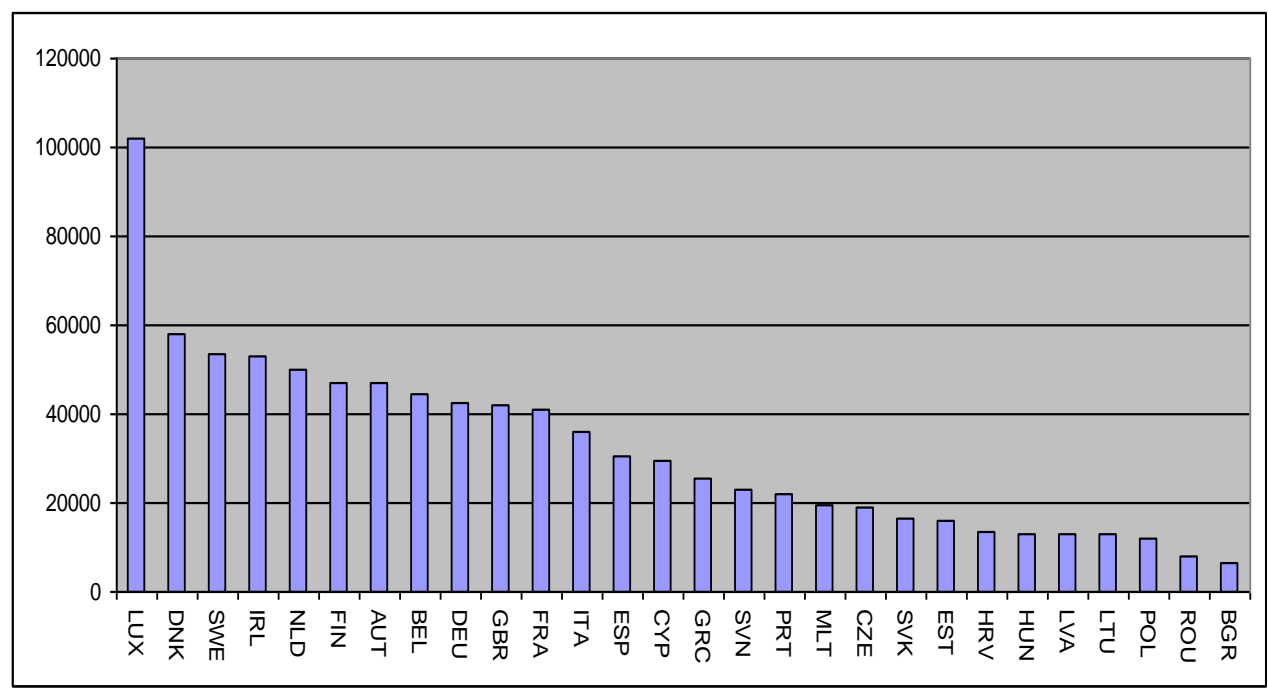

Graph 3. GDP per capita USD in EU countries between the period 2005-2014 (in Source: own view. average) 
Table 2. Descriptive statistic

\begin{tabular}{|l|r|r|r|r|r|}
\hline & $\mathrm{N}$ & \multicolumn{1}{|c|}{ Minimum } & Maximum & \multicolumn{1}{c|}{ Mean } & \multicolumn{1}{c|}{ Std. Deviation } \\
\hline COR & 28 & 1.80 & 72.70 & 34.1929 & 21.9693 \\
\hline SE & 28 & 8.50 & 32.50 & 19.9357 & $7.32814 \hat{a}$ \\
\hline GROWTH & 28 & 6437.34 & 101890.44 & 32060.7345 & 20903.8867 \\
\hline
\end{tabular}

\subsection{The results of hypotheses tests}

Hypothesis 1 examines the relationship between the level of corruption and the level of shadow economy, by analyzing the data available for EU countries between the period 2005-2014. As shown in Table 3, the value of the correlation coefficient $(\mathrm{r}=0.759)$ reflects a positive and high correlation, and is statistically significant, at the $1 \%$ significance level. When running the linear regression, a positive influence was found on the level of corruption on shadow economy and this influence was significant at the $1 \%$ level of significance (Table 4). The variation in the degree of shadow economy may be explained by the level of corruption in a proportion of $57.7 \%$. A one-point increase in the index of corruption, increases the level of shadow economy (in percent of GDP) by $0.253 \%$ points. In this study, a higher level of corruption was found to be associated with a higher level of shadow economy; therefore, hypothesis 1 is accepted. These findings are in line with those of Johnson et al. (1997), Fjeldstad (1996, 2003), Buehn and Schneider (2009) and Kaufman (2010) who also revealed corruption among most determinants for shadow economy and their empirical findings showed a positive relationship between corruption and shadow economy.

Hypothesis 2 investigated the relationship between the level of corruption and economic growth. Table 3 reveals a high and negative correlation $(r=-0.701)$ between corruption and growth, which is significant at the $1 \%$ level of significance. A higher level of corruption discourages economic growth. The coefficient of linear regression shows the same conclusion (Table 5). The variation in economic growth can be explained by corruption in a proportion of $49.1 \%$, at a significance level of $1 \%$, thus supporting hypothesis 2 . The findings of this study are in agreement with those obtained by Mauro (1995), Paldam (2003), Fjeldstad (1996, 2003), Kaufman (2010), and Ivanyna et al. (2010), Achim (2017) but contradict the findings of Beck and Maher (1986) and Jiang and Nie (2014) who found a positive relationship between corruption and economic growth.

Hypothesis 3 examined the relationship between shadow economy and economic growth. The correlation coefficient revealed a negative and high correlation $(\mathrm{r}=-$ 0.757 ) between the level of corruption and level of market capitalization at the $1 \%$ level of significance (Table 3). The regression coefficient reflects the negative 
influence of corruption on economic growth, and the variation of economic growth can be explained by the level of shadow economy in a proportion of $55.7 \%$, which is statistically significant at the $1 \%$ level of significance (Table 6). Therefore, hypothesis 3 is accepted. The findings of the present study are in line with those of Schneider and Klingmair (2004) and Kirchler (2007) who found a negative shadow economy to be an impediment of economic growth, but contradicts the theory of [38], who revealed that shadow economy, especially in corrupt countries, represents an important buffer for solving many problems such as high rate of unemployment or future usage of black money in the official economy. There are empirical findings for a corrupt country such as Romania, which show that shadow economy is consistently related to the official economy and both display similar trends on the long-run (Zaman and Goschin, 2015).

Table 2. Pearson correlation.

\begin{tabular}{|l|r|r|r|}
\hline & \multicolumn{1}{c|}{ COR } & \multicolumn{1}{c|}{ SE } & GROWTH \\
\hline COR & 1 & & \\
\hline SE & $0.759^{* *}$ & 1 & \\
\hline GROWTH & $-0.701^{* *}$ & $-0.757 * *$ & 1 \\
\hline
\end{tabular}

**Correlation is significant at the 0.01 level (2-tailed)

Table 3. Linear regression between shadow economy (SE) and corruption (COR).

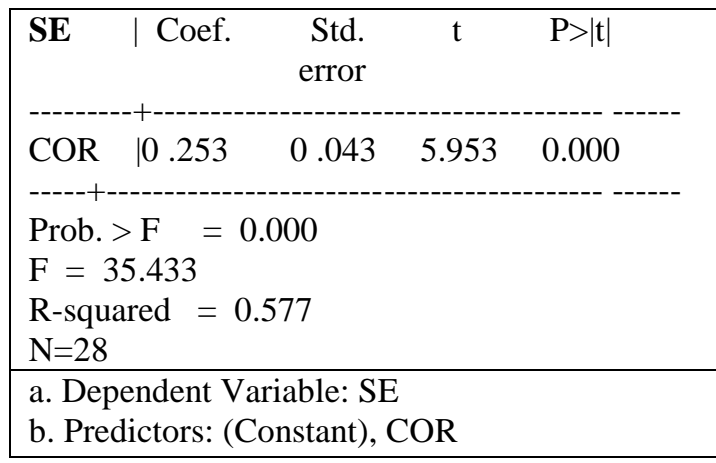


Table 4. Linear regression between growth (GROWTH) and corruption (COR)

\begin{tabular}{|c|c|c|c|c|}
\hline GROWTH & Coef. & $\begin{array}{l}\text { Std. } \\
\text { error }\end{array}$ & $\mathrm{t}$ & $\mathrm{P}>|\mathrm{t}|$ \\
\hline COR & -667.056 & 133.069 & -5.013 & 0.000 \\
\hline $\begin{array}{l}\text { Prob. }>\mathrm{F}= \\
\mathrm{F}=25.129 \\
\mathrm{R} \text {-squared }= \\
\mathrm{N}=28\end{array}$ & $\begin{array}{l}0.000 \\
0.491\end{array}$ & & & \\
\hline
\end{tabular}

Table 5. Linear regression between growth (GROWTH) and shadow economy (SE)

\begin{tabular}{|c|c|c|c|c|}
\hline GROWTH & Coef. & $\begin{array}{l}\text { Std. } \\
\text { error }\end{array}$ & $\mathrm{t}$ & $\mathrm{P}>|\mathrm{t}|$ \\
\hline SE & -2160.027 & 365.394 & -5.912 & 0.000 \\
\hline \multicolumn{5}{|c|}{$\begin{array}{l}\text { Prob. }>\mathrm{F}=0.000 \\
\mathrm{~F}=34.946 \\
\mathrm{R} \text {-squared }=0.557 \\
\mathrm{~N}=28\end{array}$} \\
\hline $\begin{array}{l}\text { a. Depender } \\
\text { b. Predictor }\end{array}$ & $\begin{array}{l}\text { Variable: GI } \\
\text { Constant), }\end{array}$ & WTH & & \\
\hline
\end{tabular}

\section{Conclusions}

After investigating the research literature, it appears that the relationship between corruption and shadow economy is still unclear. A large strand in literature associates corruption with tax evasion, due to bribery of officials by entrepreneurs, in order to stay in shadow. In this case, corruption increases shadow economy and both hamper economic development. However, some studies have shown a negative relationship between corruption and shadow economy and emphasized that corruption may lead to reduced shadow activities. Thus, entrepreneurs may bribe officials in order to obtain contract from the public sector and therefore, such contract is conducted in the official sector only. Therefore, increasing corruption could be associated with a decrease in shadow economy in exchange with a move in the official economy and thus an economic growth may occur. 
This study empirically investigated the relationships between corruption and shadow economy among the European Union countries over the period 2005-2014. Moreover, since one would expect corruption and shadow economy to be more common in poorer countries, this study also investigated how corruption and shadow economy affect the economic development of the countries in our sample.

In this study, it was found that about one-fifth of European Union GDP is lost due to shadow economy. Bulgaria, Romania, Hungary, Estonia, Greece, and Italy were found to have the highest level of corruption and shadow economy. Thus, Nordic countries such as Denmark, Finland, Sweden, Netherlands and then Austria and Luxembourg were found to have the lowest level of corruption. This study's descriptive statistics revealed that the most corrupt and shadow economies are found in low income countries, which are mainly in post-communist countries.

Further, a high and positive relationship between corruption and shadow economy was found among the EU countries, therefore a higher level of corruption result in a higher level of shadow economy. Regarding the influence of corruption and shadow economy on economic growth, a high and negative relationship was found to be associated with both. This means that increasing corruption and shadow economy negatively affected the economic growth of the EU countries during 2005-2014.

The originality of this research consists in analyzing the relationship between the two complex economic phenomena (that is, corruption and shadow economy),but generally, literature findings on this regard are quite controversial. Another unique characteristic of this research is the empirical determination of the negative role of corruption and shadow economy on economic development. The findings of this study have mainly political implications for policy-makers who need to adopt the best required incentives and policies, in order to reduce the level of corruption and shadow economy. It has been shown that among the EU countries, corruption and shadow activities will not help in solving economic problems. But, on the contrary, in this study, the indubitable negative influences of these phenomena on economic growth have been clearly and empirically determined.

In future studies, there is need to strengthen our results on the influence of corruption and shadow economy on economic development, by using some control factors which influence economic growth such as public governance, tax burden, unemployment rate as well as some cultural variables.

\section{References}

1. Achim, M. (2017), Corruption, income and business development, Journal for International Business and Entrepreneurship Development, 10(1), 85-100. 
2. Achim, M., Borlea, N.S. (2015). Determinants of the European funds absorption 20072013 in European Union Member States, Proceeding of WEI International Academic Conference in Vienna, Austria, 174-188.

3. Beck, P., Maher, M. (1986). A comparison of bribery and bidding in thin markets. Economic Letters, 20 (1), 1-5.

4. Buehn, A., Schneider F. (2009). Corruption and the Shadow Economy: A Structural Equation Model Approach, IZA DP 4182.

5. Choi, J., Thum, M. (2005). Corruption and the Shadow Economy. International Economic Review, 46 (3), 817-836.

6. De Rosa, D., Gooroochurn, N., Gorg, H. (2010). Corruption and productivity: firmlevel evidence from the BEEPS Survey. Policy Research Working Paper, World Bank, 5348,1-41.

7. Djankov, S., La Porta, R., Lopez-de-Silanes, F., Shleifer, A. (2002). The regulation of entry. Quaterly Journal of Economics, 117 (1), 1-37.

8. Dreher, A., Schneider, F. (2006). Corruption and the Shadow economy. An empirical analysis. Working paper CREMA Gellerstrasse 24-CH-4052, 1-37.

9. Fjeldsta, O.H. (2003). Fighting fiscal corruption: Lessons from the Tanzania revenue authority. Public Administration and development, 23, 165-175.

10. Fjeldstam, O.H. (1996). Tax evasion and corruption in local governments in Tanzania: Alternative economic approaches. Working Paper 14, Chr. Michelsen Institute, 1-31.

11. Ghosh S., Neanidis K. C. (2011). Corruption, Fiscal Policy, and Growth: a Unified Approach. Brunel University London, Working Paper No. 11-20, 1-42.

12. Husted, B.W. (1999). Wealth, Culture, and Corruption, Journal of International Business Studies, 30(2), 339-59.

13. Ivanyna M., Moumouras, A., Rangazas, P. (2010). The culture of corruption, tax evasion, and optimal tax policy. Available at http://www2.warwick.ac.uk/fac/soc/ economics/events/seminars-workshopsconferences/conferences/mysore/programme/ivanyna.pdf

14. Jiang, T., Nie, H. (2014). The stained China miracle: Corruption, regulation, and firm performance, Economics Letters, 123, 366-369.

15. Johnson, S., Kaufmann, D., Sleifer, A. (1997). The unofficial economy in transition. Brooking Papers on Economic Activity, 2, 159-239.

16. Kaufman, D. (2010). Can Corruption Adversely Affect Public Finance in Industrialized Countries?, Brookings Institution Opinions April 19.

17. Kirchler, E. (2007). The Economic Psychology of Tax Behavior. Cambridge University Press, Cambridge, England.

18. Mauro, P. (1995). Corruption and Growth, The Quarterly Journal of Economics, 110 (3), 681-712.

19. Mocan, N. (2008). What determines corruption? International Evidence from Micro data, Economic Inquiry, 46(4), 493-510.

20. Orviska, M., Hudson, J. (2003). Tax evasion, civic duty and the law abiding citizen. European Journal of Political Economy, 19(1), 83-102.

Studia Universitatis "Vasile Goldis" Arad. Economics Series Vol 27 Issue 2/2017

ISSN: 1584-2339; (online) ISSN: 2285 - 3065 
21. Paldam, M., Gundlach, E. (2009). The transition of corruption: From poverty to honesty, Economic Letters, 103, 146-148.

22. Paldam, M. (2002). The big pattern of corruption: economics, culture and the see saw dynamics. European Journal of Political Economy, 18, 215-240.

23. Paldam, M. (2001). Corruption and religion. Adding to the economic model. Kyklos, 54, 383-414.

24. Sahakyan, N., Stiegert , KW. (2012). Corruption and Firm Performance, Eastern European Economics, 50(6), 5-27.

25. Schneider, F., Raczkowski, K., Mróz, B. (2015). Shadow economy and tax evasion in the EU, Journal of Money Laundering Control. 18(1), 34-51.

26. Schneider, F. (2013). Size and Development of the Shadow Economy of 31 European and 5 other OECD Countries from 2003 to 2013: A Further Decline, 1-7. Available at http://www.econ.jku.at/members/schneider/files/publications/2013/shadeceurope31_ja n2013.pdf. Accessed on November 2015.

27. Schneider, F. (2011). The Shadow Economy and Shadow Economy Labor Force: What Do We (Not) Know?, IZA Discussion paper, no. 5769, 1-66.

28. Schneider, F., Buehn, A., Montenegro, C.E. (2010). New Estimates for the Shadow Economies all over the World, International Economic Journal, 24(4), 443-461.

29. Schneider, F. (2005). Shadow economies of 145 countries all over the world: estimation results of the period 1999 to 2003, Discussion Paper Linz, 1-62.

30. Schneider, F., Klinglmair, R. (2004). Shadow economies around the world: what do we know? Universität Linz, Working Paper No. 0403, 1-57.

31. Shelak, B.J. (1997). The impact of the US underground activity. A note relating to the impact on state finances. Journal of Government Information, 24(2), 113-117.

32. Torgler, B., Schneider, F. (2007). The Impact of Tax Morale and Institutional Quality on the Shadow Economy. IZA Discussion Paper, 1-46.

33. Transparency International (2016). Available at: https://www.transparency.org/. Accessed on February, 2016.

34. Treisman, D. (2000). The causes of corruption: a cross-national study. Journal of Public Economics, 76, 399-457.

35. Virta, H. (2007). Corruption and Shadow Economy: Differences in the Relationship between Countries. Discussion papers, Helsinki Center of Economic Research, 171, 126.

36. Weber, A. (2005). How far Perceptions go, Transparency Brazil Working Paper. The World Bank, Washington DC.

37. World Bank Group (2016). Available at: < www.worldbank.org > Accessed on February, 2016.

38. World Bank (2009). Anticorruption. Washington, DC.

39. Zaman, G., Goschin, Z. (2015). Shadow economy and economic growth in Romania. Cons and pros. Procedia Economics and Finance, 22, $80-87$. 